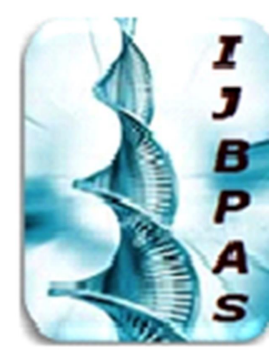

International Journal of Biology, Pharmacy and Allied Seiences (IJBPAS) 'A Bridge Betusen Caboratory and QRendor'

WWW.ijbpas.com

PREPARATION AND EVALUATION OF HERBAL EXTRACT MIXTURES (HEM) AND ITS PHYTOCHEMICAL INVESTIGATION

\title{
UMA $P^{1^{*}}$, VENKATACHALAM VV ${ }^{1}$ AND MANICHANDRIKA $P^{2}$
}

1: Department of Pharmacy, Annamalai University, Annamalai Nagar-608 002, Tamil Nadu, India

2: Bojjam Narasimhulu Pharmacy College for Women, Vinay Nagar, Champapet, Hyderabad, Telangana State, India

*Corresponding Author: E Mail: pashamuma27@gmail.com

Received $10^{\text {th }}$ Nov. 2019; Revised $4^{\text {th }}$ Dec. 2019; Accepted $18^{\text {th }}$ Jan. 2020; Available online $1^{\text {st }}$ July 2020

\section{https://doi.org/10.31032/IJBPAS/2020/9.7.5096}

\section{ABSTRACT}

The Present study was designed to prepare and evaluate the herbal extract mixtures and its phytochemical screening by using the two plants namely Moringa oleifera and Raphanus sativus. Leaves of Moringa oleifera and roots of Raphanus sativus were collected from Government Nursery, Moinabad, Hyderabad Then collected leaves and roots were authenticated from Botanical Survey of India (BSI). Phytochemical investigation was performed for both the plants, which revealed the presence of steroids, flavonoids, saponins, proteins, reducing sugar, tannins, and phenolic compounds, Proteins and glycosides. Evaluation tests like physicochemical parameters and stability testing was also performed at accelerated temperature. The results of stability of the herbal extract mixtures reveal that no changes were noticed in all the tested physiochemical parameter as well as turbidity/homogeneity during $24 \mathrm{hr}, 48 \mathrm{hr}, 72 \mathrm{hr}$ weekly once and until 30 days.

Keywords: Moringa oleifera, Raphanus sativus, Specific gravity, Turbidity, Herbal extract mixture 


\section{INTRODUCTION}

Ayurvedic herbal preparations often consist of complex mixtures of plant materials practiced in many countries of the Indian subcontinent [1]. Herbal products are being used as a home remedies worldwide in a variety of healthcare settings and are often promoted to the public as being "natural" and completely "safe" alternatives to conventional medicines [2]. Herbal medicines include dietary supplements that contain herbs, either single or in mixtures, also called botanicals [3]. The study of herbdrug interactions is among the newest areas of research affecting the modern practice of medicine. Hence, information on specific interactions may simply not be available, as the research has not yet been conducted [4]. Moringa oleifera also known as oil tree, drum stick tree, horseradish tree and miracle tree. Moringa oleifera tree specially leaves are having both nutrition value as well as medicinal importance anti-diabetics, antioxidant, anti-hypertensive, antihyperlipidemic, anti-atherosclerotic, antiulcer, anti-inflammatory, anti-bacterial, antiarsenic toxicity agents, this is because due to presences of important chemical constituents in the leaves like: - flavonoids, phenols, tannins, alkaloids, steroids, chlorogenic acid and amines, which play a key role in medicinal uses. The leaves are use as antidiabetics because it helps in insulin secretion and help in reduction of insulin resistance and utilization of glucose by the peripheral tissues and inhibition of gluconeogenesis by the liver. The radish (Raphanus sativus) is an edible root vegetable of the Brassicaceae family. The root is best harvested before the plant flowers. Old roots are used in the treatment of hypertension, cardiometabolic disorders, antimicrobial and antioxidant agent. The present study was aimed for the preparation, phytochemical investigation and evaluation of stability parameters of herbal extract mixtures.

\section{MATERIALS AND METHODS}

\section{Plant Material}

The plant Moringa oleifera and Raphanus sativus collected in the month of February Leaves of Moringa oleifera and roots Raphanus sativus of plant were collected from Government Nursery, Moinabad in Hyderabad. Then collected leaves and roots were authenticated by P.V. Prasanna, Scientist G, Botanical Survey of India (BSI), Hyderabad.After authentication plant parts were dried at optimum temperature for one week. After drying the leaves \& Roots are made into fine powder or crushed in fine powder with the help of electric mixer. 
Preparation of Hydroalcoholic extracts of Moringa oleifera leaves and Raphanus sativus roots

About $200 \mathrm{~g}$ powdered leaves of Moringa oleifera and roots of Raphanus sativus were taken separately and initially defatted with Petroleum ether by Continuous Hot Extraction (Soxhlet) and allowed the solvent to get evaporated completely. After complete drying, the above said residues were extracted with soxhlet extractor using hydro-alcohol of $30-70 \%$ ratio as solvent. The extracts were filtered using whatman filter paper and dried at room temperature. The resulting hydro alcoholic extract [5] was filtered and concentrated using rota evaporators. The crude extracts powders were preserved at low temperature for further investigation.

\section{Preparation of herbal extract mixtures}

After the extraction three different mixtures were prepared from these extracts and named as $\mathrm{A}, \mathrm{B}$ and $\mathrm{C}$ in which herbal extracts mixture A contains $50 \%$ of Moringa oleifera and 50\% Raphanus sativus, herbal extracts mixture B contains $70 \%$ of Moringa oleifera and $30 \%$ Raphanus sativus, and herbal extracts mixture C contains 30\% of Moringa oleifera and 70\% Raphanus sativus [6].

Preliminary Phytochemical Screening
A systematic study of a crude drug embraces through consideration of both primary and secondary metabolites derived as a result of plant metabolism [6,7]. The hydroalcoholic extracts were assessed for the identifying the presences of the chemical constituents by using the standard phytochemical analysis methods and the results are shown in Table 1.

\section{Test for total Flavonoids}

To the test solution of plant $95 \%$ of ethanol $5 \mathrm{ml}$ is added and a few drops of conc. $\mathrm{HCl}$ is added, to this magnesium turning were added, the solution given pink color shade which indicates the presences of flavonoids.

\section{Test for total Phenolic compounds}

To the $1 \mathrm{ml}$ test solution of plant 4 drops of ethanol is added followed by 3 drops of $0.1 \%$ of $\mathrm{FeCl}_{3}$ solution is added, red color indicates the presences of phenolic compounds.

\section{Test for total Alkaloids}

The test solution of plant is treated with few drops of dilute $\mathrm{HCl}$ and filtered, then to this filtrate Drangendroff's reagent is added, the formation of orange-brown precipitation confirms the presences of alkaloids.

\section{Test for total glycosides}

Killer-killani test:- The small amount test solution, 2-3 $\mathrm{ml}$ of cold Acetic acid is added followed by few drops of $\mathrm{FeCl}_{3}$ and concentrated $\mathrm{H}_{2} \mathrm{SO}_{4}$, if rosy shade appear 
between to junction then it confirms the presences of glycosides.

\section{Test for total carbohydrates}

Fehling`s test : Take one $\mathrm{ml}$ of Fehling`s solution A and add one $\mathrm{ml}$ of Fehling's solution $\mathrm{B}$ and then add $2 \mathrm{ml}$ of plant extract and boil for few minutes, if red colour ppt observe it confirm the presences of reducing sugar.

\section{Test for total Saponins}

Take the small quantity of sample in the test tube and add little amount of distilled water to it and shake the test tube, foam formation is seeing which confirms the presences of saponins.

\section{Test for total tannins}

To the test solution of plant add 2-3 $\mathrm{ml}$ of water followed by few drops of ferric chlorides solution, green to blue-green shade is observed.

\section{Test for total Steroids}

Libermann buchard test : to the test solution of plant add few drops of acetic anhydride and then few drops of $\mathrm{H}_{2} \mathrm{So}_{4}$ in inclined position, the green color ring is formed between two junction which confirms the presences of steroids.

\section{Test for Proteins and Amino acids}

Take small quantity of sample in the test tube add little amount of $2 \%$ copper sulphate solution to it add 95\% ethanol and $\mathrm{KOH}$ pellets if pink colored solution in ethanolic layer observe it confirms the presence of proteins.

\section{Evaluation of Herbal extract mixtures}

Physicochemical properties such as physical appearance colour, odour, taste, $\mathrm{pH}$, specific gravity was examined. [10]

Color examination: - Herbal extract mixture was taken into watch glasses and placed against white back ground in white tube light. It was observed for its color by naked eye.

Odor examination: - herbal extracts mixtures was smelled individually. The time interval among two smelling was kept 2 minutes to nullify the effect of previous smelling.

Taste examination: - A pinch of herbal extracts mixture was taken and examined for its taste on taste buds of the tongue.

Determination of $\mathbf{p H}$ : - Placed an accurately measured amount herbal extract mixture in a $100 \mathrm{ml}$ volumetric flask and made up the volume up to $100 \mathrm{ml}$ with distilled water. The solution was sonicated for about 10 minutes. $\mathrm{pH}$ was measured with the help of digital $\mathrm{pH}$ meter.

Specific gravity at $25^{\circ} \mathrm{C}$ :- A thoroughly clean and dry Pycnometer was selected and 
calibrated by filling it with recently boiled and cooled water at $25^{\circ} \mathrm{C}$ and weighing the contents. Assuming that the weight of $1 \mathrm{ml}$ of water at $25^{\circ} \mathrm{C}$ when weighed in air of density $0.0012 \mathrm{~g} / \mathrm{ml}$ was $0.99602 \mathrm{~g}$. The capacity of the Pycnometer was calculated.

\section{Stability Testing}

For the prepared herbal extracts mixtures Stability testing [10] was performed for the at different temperature conditions. Three mixtures (A, B and C) were taken in amber colored glass bottles and were kept at the temperature at $30^{\circ} \mathrm{C}$, Room temperature and $37^{\circ} \mathrm{C}$ respectively. All the three mixed extracts samples were tested for physicochemical parameters, homogeneity and turbidity at the interval of $24 \mathrm{hr}, 48 \mathrm{hr}$, $72 \mathrm{hr}$, weekly once and until 30days to observe any change.

\section{RESULTS AND DISCUSSION:-}

\section{Preliminary Phytochemical Screening}

Preliminary phytochemical screening of the hydroalcoholic extracts of Moringa oleifera (leaves) and Raphanus sativus (Roots) contains steroids, flavonoids, saponins, proteins, reducing sugar, tannins, and phenolic compounds, and glycosides. The results were shown in Table 1.

\section{Stability Testing}

Immediately after preparation, herbal extracts mixtures was evaluated for all the tested parameter along with turbidity/homogeneity which was compared with the changes in accelerated stability testing. The final mixed extracts found to have $\mathrm{pH} \quad 6.25$ and specific gravity $1.09 \mathrm{~g} / \mathrm{ml}$ (Table 2). The results of stability study of the herbal extracts mixtures reveal that no changes were noticed in all the tested physicochemical parameter as well as turbidity/homogeneity during 24 hr, $48 \mathrm{hr}, 72 \mathrm{hr}$ and until 30days [8-10]. Thus it can be concluded that the prepared herbal extracts mixtures may be used for a preparation of stable dosage form and the results of the stability study may help for further studies of herbal extracts mixture in near future .

Table 1: Preliminary phytochemical screening of hydroalcoholic extract of Moringa oleifera \& Raphanus sativus
\begin{tabular}{|c|c|c|}
\hline Chemical Constituents & $\begin{array}{c}\text { M.oleifera Hydroalcoholic } \\
\text { extract }\end{array}$ & $\begin{array}{c}\text { Raphanus sativus Hydroalcoholic } \\
\text { extract }\end{array}$ \\
\hline Carbohydrates & + & + \\
\hline Glycosides & + & + \\
\hline Alkaloids & + & - \\
\hline Flavonoids & + & + \\
\hline Phenols & + & - \\
\hline Fixed oils & - & - \\
\hline Steroids & + & + \\
\hline Saponins & + & - \\
\hline Proteins \& free amino acids & + & \\
\hline
\end{tabular}

(+) Present; (-) Absent 
Table 2: Result of Physicochemical parameters of developed Herbal extract mixtures

\begin{tabular}{|c|c|c|}
\hline S. No & $\begin{array}{c}\text { Physicochemical } \\
\text { Parameters }\end{array}$ & Observed Values \\
\hline 1 & Color & Light Green \\
\hline 2 & Odour & Pleasant odor \\
\hline 3 & Taste & Bitter \\
\hline 4 & P $^{\text {II }}$ & $\mathbf{6 . 2 5}$ \\
\hline 5 & Specific Gravity & $\mathbf{1 . 0 9 g} / \mathbf{m l}$ \\
\hline
\end{tabular}

\section{CONCLUSION}

In conclusion, the present study demonstrated the development of herbal extracts mixtures (HEM) of the hydroalcoholic extracts of Moringa oleifera and Raphanus sativus in various concentrations. The prepared HEM was evaluated immediately after preparation and all the tested parameter along with turbidity/homogeneity were compared with the changes in accelerated stability testing. The final mixed extracts found to have $\mathrm{pH} 6.25$ and specific gravity 1.09 $\mathrm{g} / \mathrm{ml}$ (Table 2). The results of stability study of the final mixed extracts reveal that no changes were noticed in all the tested physicochemical parameter as well as turbidity/homogeneity during $24 \mathrm{hr}, 48 \mathrm{hr}$, $72 \mathrm{hr}$ until 30days. Thus it can be concluded that the prepared HEM may be used for the preparation of stable dosage form and the results of the accelerated stability study may help for further studies in near future.

\section{REFERENCES}

[1] KPRC Prasad, PGD Tharangani. 2009. CN Samaranayake. Recurrent relapses of depression in a patient established on sertraline after taking herbal medicinal mixtures-a herbdrug interaction. $J$ of Psychopharmacol. 23 (2): 216-219.

[2] K. Chan.2003. Some aspects of toxic contaminants in herbal medicines. Chemosphere. 52: 1361-137.

[3] KJ Gohil, J A Patel. 2007. Herb-drug interactions: A review and study based on assessment of clinical case reports in literature. Indian $J$ Pharmacol. 39(3): 129-139.

[4] Ernst E, Pittler MH.2008. Herbal medicine. Med Clin North Am. 86(1): 149-61.

[5] Subhash T. Kumbhara, Shriniwas P. Patilb, Hemant D. Unec, Phytochemical analysis of Canna indica L. roots and rhizomes extract Biochemistry and Biophysics Reports 16(2018) 50-55. 
[6] Ms. S. Dhanalakshmi, Aleema shahada U, Lakshmi. M, Lokesh. K, Sangeetha. G.2017. Anti-Diabatic Activity of Herbal Extract Mixture. Journal of Pharmacy Research 2017,11(4),278-280

[7] Paikra BK, Dhongade HKJ, Gidwani B. Phytochemistry and Pharmacology of Moringa oleifera Lam. J Pharmacopuncture. 2017 Sep; 20(3): 194-200

[8] Bhattacharya A, Tiwari P, Sahu KP, Kumar S. 2018. A review of the phytochemical and pharmacological characteristics of Moringa oleifera. $J$ of Pharm bio allied sci. 10(4): 181191
[9] Manish Kumar Thimmaraju, Prasenjit Mondal, Kola Venu, Bookya Padmaja, Gummadi Sridhar Babu, Rudra Dinesh Kumar, and Konda Ravi Kumar. Carbon Tetrachloride, Alcohol and Ranitidine Induced Hepatotoxicity and Its Protection by Bark Extracts of Bassia latifolia in Wister Rats. J. of herbs, spices \& medicinal plants. 2020. 26(1). 1-16

[10] Pramod Kumar S, Prasan ND. Design, Development \& Evaluation of a Poly herbal Syrup from some herbs used as Energy booster. Int. J. of Ayurvedic Medicine, 2013, 4(4), 374-378. 